\title{
Intrathyroid Thymic Carcinoma
}

National Cancer Institute

\section{Source}

National Cancer Institute. Intrathyroid Thymic Carcinoma. NCI Thesaurus. Code C46106.

A rare primary carcinoma of the thyroid gland, composed of groups of carcinoma cells with thymic epithelial differentiation. 